\title{
VZDELÁVACIE AKTIVITY ZAMERANÉ NA GEOGRAFIU V PREDPRIMÁRNOM VZDELÁVANÍ
}

\author{
Michaela Žoncová, Jana Vojteková
}

\begin{abstract}
Pre-primary education can be described as the beginning of a formal education process of a child. This education takes place in kindergartens, where children are usually admitted from three to six years of age. Kindergarten supports the development of children's personal development, develops skillfulness and abilities, shapes prerequisites for further education, and prepares for life in society. The areas of education and standards are also determined in legislation i.e in the State Educational Program for Pre-primary Education at Kindergartens. It is therefore necessary to start building a relationship with nature and landscape already in this period using appropriately chosen methods. The aim of the article is to point out educational activities in geography for kindergartens used at the Children's Day of Science. The article describes 5 activities that are focused on orientation on the Earth, map reading, creating links between popular fairy tales and real world or identifying animals and their natural environment for life.
\end{abstract}

Keywords: pre-primary education, geography, didactics, game

\section{Úvod}

Problematikou dôležitosti získavania geografických vedomostí už v predprimárnom vzdelávaní sa zaoberali už Desart a Trytten (1962), ktorí vo svojej práci zdôrazňujú fakt, že deti sú už od svojho detstva fascinované prírodou vo svojom prirodzenom okolí a preto už v škôlke sa naskytujú ideálne predispozície rozvíjat' ich zvedavost'. V súčasnosti neustále klesá záujem o prírodné vedy a preto je potrebné vzbudit' záujem detí už v útlom veku hravými a zaujímavými aktivitami. Štátny pedagogický ústav Slovenskej republiky preto vydal Štátny vzdelávací program pre predprimárne vzdelávanie v materských školách, $\mathrm{v}$ ktorom ustanovuje základné požiadavky štátu na poskytovanie inštitucionálneho predprimárneho vzdelávania vo všetkých materských školách v Slovenskej republike. Rovnako ako vo vzdelávacích programoch pre základné a stredné školy, aj tu sú presne definované vzdelávacie oblasti. Jednou z oblastí je „Človek a príroda“, v ktorej sa kladie dôraz na počiatočný rozvoj prírodovednej gramotnosti. Priebeh vzdelávacích činností je postavený na podnetných, stimulujúcich situáciách, ktoré vzbudzujú u detí snahu poznávat' prírodné reálie. Medzi prírodovedné spôsobilosti, ktoré je možné v predškolskom veku rozvíjat', patrí pozorovanie (ciel'avedomé získavanie nových informácií $\mathrm{z}$ prostredia), 
kategorizovanie (porovnávanie a triedenie na základe cieleného pozorovania) a empirická komunikácia (vyjadrená argumentáciou vlastnou skúsenost'ou). Táto vzdelávacia oblast' sa člení do nasledujúcich podoblastí:

- Vnímanie prírody,

- Rastliny,

- Živočíchy,

- Človek,

- Neživá príroda,

- Prírodné javy.

Ciel'om príspevku je vytvorenie vzdelávacích aktivít zameraných na geografiu pre deti v predškolskom veku a ich aplikácia v praxi.

\section{Teoreticko-metodické východiská}

Diet’a $v$ predprimárnom veku neprijíma informácie a neučí sa pasívne, ale skôr získava poznatky a rozvíja svoje myšlienkové procesy na základe vlastných činností v procese interakcie so svetom. Najefektívnejšie učenie prebieha vtedy, ked' diet'at'u prichádzajúca informácia sa prepája so skúsenost'ami, schémami a vlastnými konceptmi subjektu, čím sa ulahčuje proces jej spracovania a ukladania (Gužíková, 2016). Tento proces prepájania skúseností popísal vo svojej teórií aj Piaget (1970), ktorý navrhol, aby vyučovanie stavalo na predchádzajúcich skúsenostiach a vedomostiach žiakov a aby sa všetky nové poznatky vtkali už do existujúceho rámca detských teórií bez ich významnejšieho narušenia. S tým úzko súvisí predstava o tom, akým spôsobom diet’a učit' tak, aby do výučby boli zakomponované jeho predchádzajúce skúsenosti.

Práve informácie $\mathrm{z}$ geografie je vhodné $\mathrm{v}$ predprimárnom vzdelávaní podávat' det'om takou formou, aby si ich vedeli spojit' s vlastnými zážitkami a doterajšími poznatkami. Ked’že objektom geografie je krajina a skúmanie priestorových zákonitostí rozmiestnenia objektov, javov a procesov v krajine, je možné zakomponovat' geografické témy vel'mi jednoducho a účelne aj do procesu predprimárneho vzdelávania. Podl'a Rochovskej a Krupovej (2012) by sa malo s prírodovedným vzdelávaním začat' už $\mathrm{v}$ materskej škole, lebo diet’a je práve $\mathrm{v}$ tomto veku vel'kým objavitel'om vecí, objektov, javov a je dôležité ho usmernit' a poskytnút čo najviac podnetov pre bádanie a skúmanie sveta okolo seba.

Didaktické aktivity v predprimárnom vzdelávaní sa skladajú z rozmanitých hier a výchovno-vzdelávacích činností, ktoré sa vzt’ahujú na ciele a obsah jednej, alebo niekol'kých výchovných zložiek realizovaných súbežne. Časové trvanie didaktických aktivít je determinované sústredenost'ou a záujmom konkrétneho diet’ata o danú činnost' (Guziová, 1999).

Prvým a základným krokom pri vzdelávacích aktivitách v predprimárnom vzdelávaní by mala byt' zábava, ktorá môže byt' vyvolaná prostredníctvom hry, pri 
ktorej sa však deti zároveň aj niečo naučia. Hra môže byt' realizovaná aj pomocou názorných ukážok, kedy deti zapoja svoju predstavivost' a vedia tak javy a procesy lepšie pochopit'. Uplatňovanie princípu názornosti vedie k zvyšovaniu efektívnosti pri učení sa žiaka, povzbudzuje jeho záujem a ul'ahčuje zapamätanie. Medzi základné prostriedky, uplatňujúce princíp názornosti vo vyučovaní geografie, patrí hra a experiment (Kalakay, 2001). Didaktické hry, úlohy a experimenty by nemali chýbat' pri každom modernom vyučovacom procese. Školská prax potvrdzuje, že ak žiakovi nie je niečo jasné, nemá to rád. Ked' mu učitel' ukáže alebo naznačí cestu hl'adania riešenia, napríklad prostredníctvo hry alebo úlohy, žiak to nebude chápat' ako prít’až alebo námahu, ale skôr ako zábavu.

Hra by mala podl'a Hricovej, Jakubíkovej a Tulenkovej (2003) spíňat' tieto podmienky:

- dostatočne prít’ažlivý námet,

- primerane t’ažká úloha (individuálna alebo skupinová),

- jasné a premyslené pravidlá,

- múdra motivácia,

- významnú rolu zohráva aj prostredie a celková atmosféra.

Hra rozvíja individuálne zručnosti, schopnosti a vlastnosti, napr.: samostatnost', zodpovednost', komunikáciu, schopnost' diskutovat', pracovat' v tíme, takticky mysliet', učit' sa znášat' porážky, rešpektovat' súpera, ovplyvňovat' psychickú odolnost', sebavedomie a sebadôveru. Pomáha nám lepšie poznat' svoje miesto medzi l'ud'mi a tiež nám pomáha lepšie poznat' tento svet. Má značný vplyv na kognitivizáciu, motiváciu a aktivizáciu, emocionalizáciu, socializáciu, komunikáciu a kreativizáciu žiakov.

Okrem hry je v predprimárnom vzdelávaní vhodnou metódou aj experiment. $\mathrm{Z}$ jednej strany je experiment chápaný ako postup, ktorý prebieha plánovane krok za krokom podl'a vopred pripravenej schémy. Z druhej strany je experiment procesom, $\mathrm{v}$ ktorom sa spája geografický proces s procesom myslenia a poznania. Experiment ako metóda poznania sa zakladá na pozorovaní reálne existujúcich objektov upravených tak, aby sa umožnilo alebo zjednodušilo ich skúmanie (Koubek a kol., 1992).

Pri vytváraní nižšie uvedených didaktických aktivít pre deti materskej školy sa kládol dôraz na výkonnostné a obsahové štandardy zakotvené v Štátnom vzdelávacom programe pre predprimárne vzdelávanie $\mathrm{v}$ materských školách. Zameriavajú sa najmä na vzdelávaciu oblast' Človek a príroda, do ktorej obsahovo najviac zapadajú geografické aktivity. Aktivity boli vytvárané tak, aby ich príprava nebola finančne a časovo náročná a aby pomôcky $\mathrm{k}$ aktivitám mohli byt' viacnásobne použité. Mapy a kartičky k aktivitám boli vytvárané na podkladových obrázkoch z portálu Freepik.com, ktorý poskytuje bezplatne vektorovú grafiku. Aby bola aktivita pre deti zaujímavá, boli uprednostnené pútavé obrázky a následne boli upravené v programe Adobe Illustrator. 


\section{Výsledky}

Pri príležitosti Medzinárodného dňa detí je od roku 2015 každoročne organizované podujatie Vedecký deň detí - VEDET na Fakulte prírodných vied Univerzity Konštantína Filozofa v Nitre, ktoré je určené pre deti z materských škôl a žiakov prvých ročníkov základných škôl z mesta Nitry. Ide o podujatie zamerané na prírodovedné vzdelávanie hravou formou. Deti sa na pár hodín stanú vedcami v oblasti fyziky, matematiky, biológie, geografie, ale aj ekológie a pod. Každoročne na podujatie prichádza približne 400 detí z materských škôl a žiakov prvého ročníka ŽS.

Didaktické hry a experimenty zamerané na geografiu ako prírodnú vedu využité na tomto podujatí boli orientované najmä na kartografiu, klímageografiu, biogeografiu a regionálnu geografiu. Didaktické hry a experimenty boli pripravené veku primeranej ciel'ovej skupine a obsah aktivít bol zameraný na podporu kongnitivizácie, motivácie, aktivizácie, emocionalizácie, komunikácie, ale aj kreativizácie u detí.

\section{Didaktická hra 1: Č́tanie mapy}

Č́tanie mapy sa môže zdat' na prvý dojem náročná aktivita pre deti v predškolskom veku, avšak ak je táto aktivita spojená s osobným zážitkom detí alebo s oblúbenou rozprávkou, deti si tak vedia takúto vec ovel'a jednoduchšie spojit' s miestom na mape. S det'mi je v tejto aktivite možné diskutovat' o tom, aké farby vidia na mape, čo tieto farby znamenajú, aké symboly vedia na mape identifikovat' a pod. (Kenyon, Coffey, Kroeger, 2016).

Ciel'om aktivity bolo určenie významu farieb na mape Slovenska a následné priradenie obrázkov $\mathrm{k}$ jednotlivým farbám, čo det’om nerobilo problémy (obr. 1).

Obr. 1: Mapa a kartičky k aktivite "Č́́tanie mapy” a ukážka realizácie aktivity Figure 1: Map and cards for "Map reading" activity and its demonstration

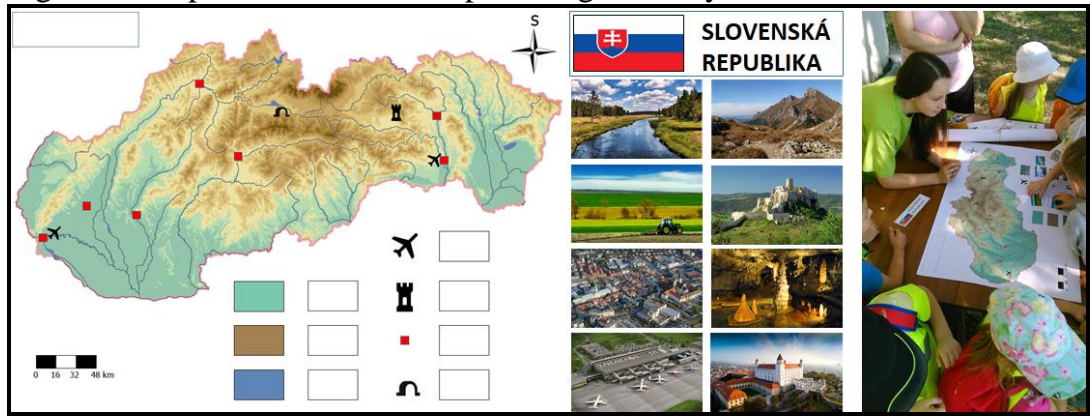

Zdroj: vlastné spracovanie, 2018, podklady z freepik.com 
Ďalej mali určit’ aj význam niektorých kartografických značiek (jaskyňa, hrad, letisko) a taktiež k nim priradit' prislúchajúci obrázok. Po ukončení aktivity bol s det'mi vedený rozhovor o tom, či poznajú niektoré hrady a jaskyne na Slovensku a či niektoré $z$ nich aj navštívili. Vo výkonostných štandardoch je stanovené, že diet'a by malo vediet' pri opise krajiny vediet' používat' pojmy ako vrch, les, pole, lúka, potok, rieka, jazero či poznat' najznámejšie prírodné krásy regiónu, či najznámejšie prírodné útvary našej vlasti, napr. Vysoké Tatry alebo Dunaj.

Deti vedeli určit' základné farby na mape a priradit’ ich k obrázku. Taktiež vedeli identifikovat' aj symbol mesta na mape a vedeli pomenovat' aj hlavné mesto Slovenska. Deti spontánne reagovali a rozprávali o svojich zážitkoch z návštevy hlavného mesta. Taktiež vedeli identifikovat' kartografickú značku hradu a vedeli niekol'ko hradov Slovenska aj vymenovat'. Problém im robila kartografická značka jaskyne, avšak po slovnom navedení a vhodnými nápovedami (miesto pod zemou, kde žijú netopiere a pod.) na to deti prišli. Táto aktivita pomáha detom $\mathrm{k}$ základnému porozumeniu mapy a jej obsahu. Deti si vedia vytvorit' súvislosti medzi farbami či piktogramami v mape a ich reálnou podobou (hnedá farba na mape - pohoria, t.j. obrázok pohoria; modrá farba na mape - vodné toky a plochy, t.j. obrázok rieky, červené body na mape - mestá, t.j. obrázok sídla; piktogram lietadla na mape - letisko, t.j. obrázok lietadiel na letisku a pod.)

\section{Didaktická hra 2: Rozprávkový svet}

Ciel’om tejto aktivity bolo na základe známych rozprávkových postavičiek (Pinokio, Máša, Mulan, Coco, Bella a pod.) spoznat' jednotlivé kontinenty, resp. štáty sveta. Úlohou detí bolo priradit' svojich oblúbených rozprávkových hrdinov na mapu sveta, podl'a toho z kadial' daná postavička pochádza. Mapa sveta bola vytvorená s pomôckami - bublinami z miesta, kde rozprávková postavička pochádzala, v ktorej boli uvedení vedl'ajší hrdinovia z danej rozprávky (obr. 2).

Deti táto aktivita vel'mi zaujala a nerobilo im problém priradit' svojich hrdinov na miesto odkial' pochádzajú. Det’om bolo vysvetlené, že tak ako oni priradili svojich hrdinov na jednotlivé miesta na svete, tak aj v skutočnosti na rôznych miestach sveta žijú l'udia. Nakoniec sa zopakovali jednotlivé kontinenty a štáty, z ktorých pochádzali rozprávkový hrdinovia, pričom deti sami mali odpovedat' na otázky, ako napr. “Odkial' pochádza Máša?” Odkial' je Mc Queen? a pod.", ak odpoved' nevedeli, ešte raz sa im zopakovali jednotlivé štáty a kontinenty.

Mnohé z detí po dokončení uvedenej aktivity vedeli rozoznat' jednotlivé kontinenty, ktoré predtým nepoznali. Táto aktivita môže byt' realizovaná aj na interaktívnej tabuli. 
Obr. 2: Mapa a obrázky k aktivite "Rozprávkový svet” a ukážka realizácie aktivity Figure 2: Map and pictures for the "Fairy world" activity and its demonstration

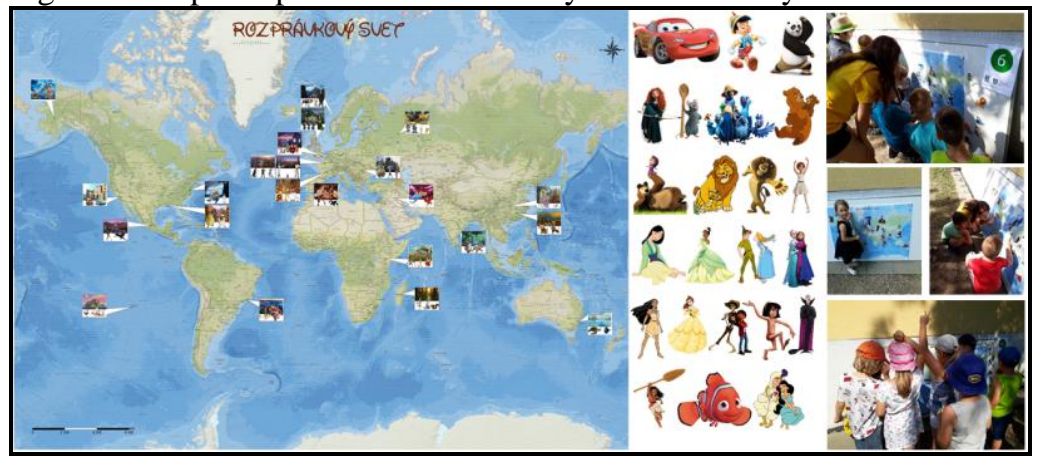

Zdroj: vlastné spracovanie, 2018; podklady z Freepik.com

\section{Didaktická hra 3: U zvieratok doma}

Ciel'om tejto aktivity bolo správne identifikovanie prirodzeného prostredia živočíchov, t.j. určenie typu krajiny, kde sa živočích prirodzene vyskytuje. Deti si tieto spojitosti urobia už počas bežného života, napríklad pri sledovaní rozprávok, kde vidia, že lev sa pohybuje po savane alebo t’ava po púšti. Aktivita bola na začiatku obohatená o sút'aživost' detí, ked’že jednotlivé postavičky zvieratiek boli rozmiestnené po areáli v ich okolí (na strome, na zemi, v kríkoch) a ich úlohou bolo čo najrýchlejšie zvieratá nájst' a priniest'. Akonáhle boli všetky kartičky zvierat pozbierané, deti ich pomenovali a po jednom spoločne zarad'ovali do správneho typu krajiny (obr. 3). Vo výkonostných štandardoch je určené, že diet’a by malo vediet' identifikovat' rôznorodost' živočíšnej ríše (napr. odlíšit' lesnú zver, domáce zvieratá, vodné živočíchy a pod.). Takouto zábavnou aktivitou sa deti naučia rozlišovat' prirodzené prostredie živočíchov sveta, hl'adajú spoločné znaky týchto druhov zvierat a učitel' s nimi môže diskutovat' aj o odlišných podmienkach pre život (teplota, vegetácia, potrava a pod.)

Pri tejto aktivite deti zarad'ovali niektoré zvieratá aj do viacerých typov krajín, čo však nie je nesprávne. S det'mi sme viedli rozhovor, prečo dané zviera zaradili do daného typu krajiny, rozdel'ovali sme morské a suchozemské zvieratá, lesné zvieratá, či zvieratá z trópov a subtrópov.

\section{Didaktická hra 4: Kde ma môžeš nájst’?}

Ciel'om tejto aktivity bolo umiestnenie vystrihnutých postavičiek zvieratiek na mapu sveta na základe ich obrysov (obr. 4). Táto aktivita bola realizovaná následne po aktivite $\mathrm{s}$ názvom "U zviertok doma", kde sa deti naučili, $v$ akom prirodzenom prostredí zvieratá žijú. V tejto aktivite však mali nálepky zvieratiek 
priradit' $\mathrm{k}$ ich pozícii na mape sveta, ked' si prirodzene vytvorili spojitosti a súvislosti, v ktorej časti sveta aké zvieratá žijú a zároveň ako sa odlišuje krajina $\mathrm{v}$ rôznych častiach sveta. Následne všetky zvieratá pomenovali a s pomocou učitel'a pomenovali aj svetadiely.

Nakoniec bol s det'mi vedený rozhovor o tom, ktoré zvieratá videli naživo, kde ich videli a čím sú charakteristické. Táto aktivita môže byt' realizovaná aj na interaktívnej tabuli.

Obr. 3: Kartičky k aktivite "U zvieratok doma" a ukážka realizácie aktivity Figure 3: Activity cards "At home at animals" and its demonstration

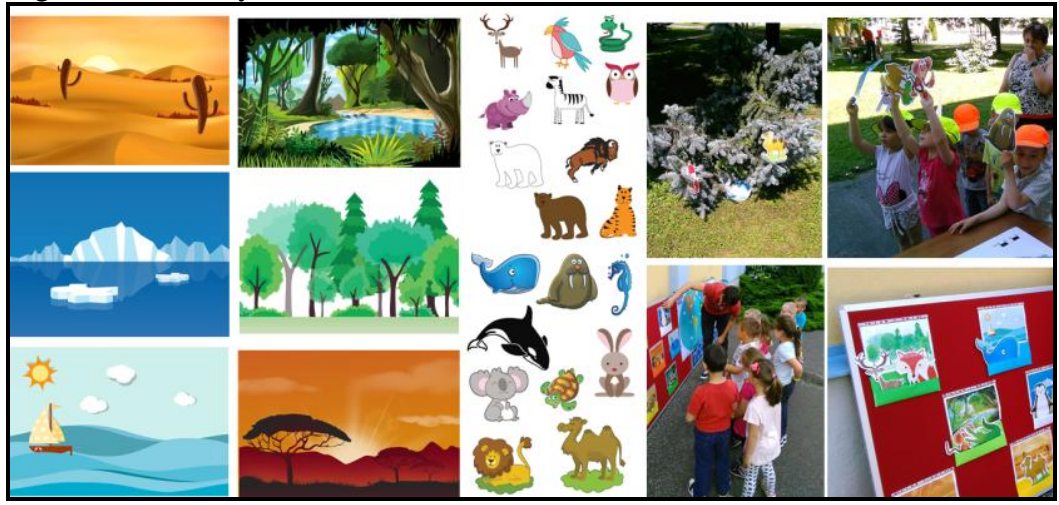

Zdroj: vlastné spracovanie, 2018; podklady z Freepik.com

Obr. 4: Mapa a kartičky k aktivite "Kde ma môžeš nájst?" a ukážka realizácie aktivity

Figure 4: Map and activity cards "Where can you find me?" and its demonstration

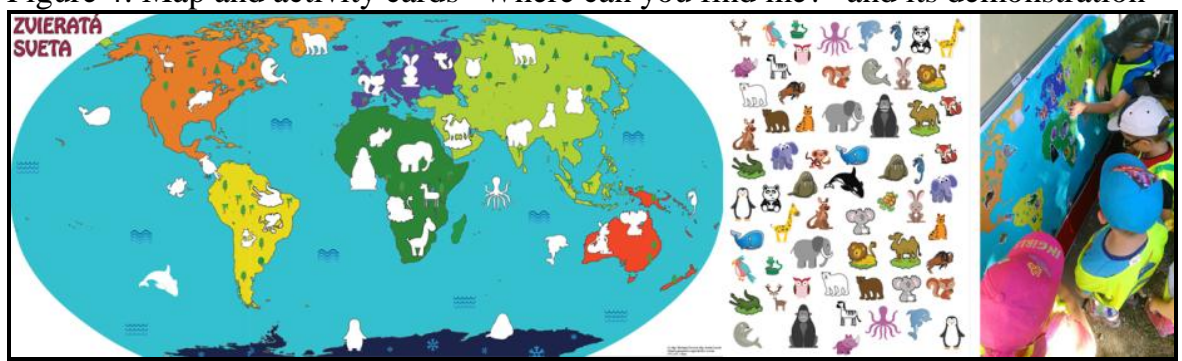

Zdroj: vlastné spracovanie, 2018; podklady z Freepik.com

\section{Didaktický experiment 5: Oblak vo fl'aši}

Ciel'om aktivity bolo naučit' deti pomocou jednoduchého experimentu ako vznikajú oblaky v atmosfére. 
Deti na základe vlastného pozorovania a skúmania zistili ako vznikajú oblaky. Tento jednoduchý experiment pozostával zo sklenej uzatváratel'nej nádoby, l'adu a horúcej vody. Počas experimentu bol s det'mi vedený rozhovor o tom, čo je to atmosféra, v ktorej časti atmosféry vznikajú oblaky, aké oblaky poznáme a pod. Ked'že aktivita prebiehala v exteriéri, det’om sa názorne popísali oblaky, ktoré $\mathrm{v}$ danú dobu mohli vidiet'. Po ukončení aktivity deti vedeli v jednoduchosti popísat' ako vznikajú oblaky, aké druhy oblakov existujú a čo je atmosféra.

Obr. 5: Ukážka realizácie aktivity Oblaky vo fl’aši

Figure 5: Demonstration of the activity "Clouds in Bottle"

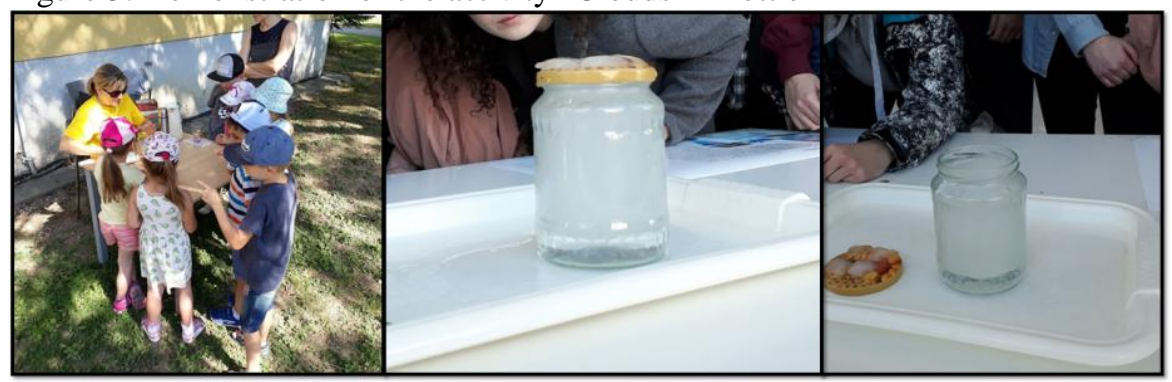

Zdroj: autori, 2018

Podl'a štátneho vzdelávacieho programu pre predprimárne vzdelávanie v materských školách je jednou z tém vo vzdelávacej oblasti Človek a príroda aj identifikovanie prvkov počasia ako aj základný opis prírodných javov ako je napríklad aj vyparovanie. Deti tak na praktickom príklade lepšie porozumejú procesu vzniku oblakov.

\section{Záver}

V procese formálneho vzdelávania sú materské školy významným elementom a poskytujú tak ucelený súbor informácií z rôznych sfér. Dôležitost' predprimárneho vzdelávania je zakotvená aj v legislatíve v Štátnom vzdelávacom programe pre predprimárne vzdelávanie $\mathrm{v}$ materských školách, kde sú definované výkonové a obsahové štandardy $\mathrm{v}$ jednotlivých vzdelávacích oblastiach. Vzdelávacia oblast' “Človek a príroda” obsahuje aj vel'kú čast' geograficky ladených tém. Ciel'om príspevku bolo vytvorit' vzdelávacie aktivity zamerané na geografiu pre deti v predškolskom veku a aplikovat' ich aj v praxi. Nami vytvorené didaktické hry sme aplikovali na podujatí VEDET (Vedecký deň detí) na Fakulte prírodných vied Univerzity Konštantína Filozofa v Nitre v rokoch 2016, 2017 a 2018. Každoročne sa tohto podujatia zúčastnilo približne 350 - 400 detí z 
materských škôl a prvých ročníkov základných škôl z mesta Nitra. Metodiky pre prvé štyri aktivity (Čitanie mapy, Rozprávkový svet, U zvieratok doma, Kde ma môžeš nájst??) boli navrhnuté a realizované autorkami. Aktivity boli vytvárané $\mathrm{s}$ rôznorodým zameraním a prvotným ciel'om bolo deti zaujat' pútavým a hravým prevedením. Prvá aktivita bola zameraná na základné porozumenie obsahu mapy (farby, symboly). Druhá aktivita bola zameraná na spoznávanie jednotlivých kontinentov a štátov sveta na základe toho, odkial' pochádzajú jednotlivé rozprávkové bytosti. Tretia a štvrtá aktivita vzájomne súviseli a boli zamerané na určenie prirodzeného prostredia zvierat a ich následná lokalizácie na mape sveta. Piata aktivita bola zameraná na pozorovanie vzniku oblakov.

Didaktické hry a experimenty použité na podujatí VEDET rozširujú vyučovanie geografie o nové prvky a obohacujú deti v predškolskom veku o nové zážitky. Postupným zarad'ovaním didaktických hier a experimentov z oblasti geografie, nielen do vyučovacieho procesu, si deti - žiaci nájdu v geografii zál'ubu a bude v ich živote patrit' medzi oblúbené predmety. Podujatie VEDET sa snaží neformálnou a hravou formou približit' det'om v predškolskom veku, ale aj žiakom prvého ročníka ZŠ geografiu ako zaujímavú a pre život dôležitú vedu.

\section{Pod'akovanie}

Príspevok bol spracovaný v rámci projektu KEGA 002UMB-4/2017 „Interaktívna elektronická učebnica regionálnej geografie Horného Pohronia“.

\section{Literatúra}

DESART, H. - TRYTTEN, U. 1962. Geographic Readiness in the Kindergarten. In Journal of Geography. ISSN 0022-1341, 1962, vol. 60, no. 7, pp. 331 - 337

GUZIOVÁ, K. 1999. Program výchovy a vzdelávania detí v materských školách. Bratislava: Ministerstvo školstva Slovenskej republiky, 1999. 182 s. ISBN 80967721-1-2.

GUŽÍKOVÁ, Ž. 2016. Metodický materiál $k$ výskumne ladenej koncepcii prírodovedného vzdelávania 3. Šal'a: Spoločnost' pre predškolskú výchovu, 2016. 187 s. ISBN 978-80-972216-1-4.

HOGGAN, D. 2002. Challenges, Strategies, and Tools for Research Scientists. In Electronic Journal of Academic and Special Librarianship. ISSN 1525-321X, 2002, vol. 3, no. 3 .

HRICOVÁ, I. - JAKUBÍKOVÁ, J. - TULENKOVÁ, M. 2003. Hry a kolektívne úlohy v prírodopise. Prešov : Metodicko-pedagogické centrum, 2003. 56 s. ISBN 80-8045-294-6.

KALAKAY, R. 2001. Demonštračný experiment vo vyučovani fyziky. [online]. [cit. 2018-09-20]. Dostupné na internete: <http://physedu.science.upjs.sk/sis/fyzika/ experimenty/demonstracne/index.htm>. 
KENYON, E. - COFFEY, C. - KROEGER, J. 2016. "Hey, I've Been There!" Using the Familiar to Teach World Geography in Kindergarten. In Social Studies and the Young Learner. ISSN 1056-0300, 2016, vol. 29, no. 2, pp. 4-7. KOUBEK, V. - BUKOVEN, P. - CHALUPKOVÁ, A. - JANOVIČ, J. KORCSOKOVÁ, A. - PECHO, A. 1992. Školské pokusy z fyziky. Bratislava: SPN, 1992. $501 \mathrm{~s}$.

PIAGET, J. 1970. Science of education and the psychology of the child. New York: Viking, 1970. $186 \mathrm{p}$.

ROCHOVSKÁ, I. - KRUPOVÁ, D. 2012. Inovácie v predprimárnom prírodovednom vzdelávaní. In Predprimárne vzdelávanie v súčasnosti. Prešov: Prešovská univerzita v Prešove, Slovenský výbor Svetovej organizácie pre predškolskú výchovu, 2012. ISBN 978-80-555-0703-3.

\section{EDUCATIONAL ACTIVITIES FOCUSED ON GEOGRAPHY IN PRE-PRIMARY EDUCATION}

\section{Summary}

The article deals with the acquisition of geographic knowledge in preprimary education through didactic games and experiments. The aim of the paper was to create educational activities focused on geography for pre-school children and to test them in practice. Didactic games and geography experiments were applied to the VEDET event (Children's Science Day) which was designed for preschool children as well as 1 st level primary school pupils.

Games develop individual skills, abilities and qualities such as: autonomy, responsibility, communication, ability to discuss, work in a team, tactical thinking, learning to defeat, respecting the opponent, influencing psychological resilience, and self-confidence. It helps us to better know our place among people and also to better know this world. It has a significant impact on cognitivization, motivation and activation, emotionalization, socialization, communication and creativity of pupils. In addition to the game, experiments are a suitable method for pre-primary education. On the one hand, the experiment is understood to be a step-by-step process according to a pre-prepared scheme. On the other hand, the experiment is a process that links the geographic process with the process of thinking and knowing. The experiment, as a method of knowledge, is based on the observation of actually existing objects modified to allow or simplify their exploration (Koubek et al., 1992).

In creating didactic activities for children of kindergartens, the emphasis was placed on the performance and content standards which are included in the State Educational Program for Pre-primary Education at Kindergartens. They are focused primarily on the education area called Man and Nature for which the geographical activities are the most suitable. The activities were created in such a 
way that their preparation has not been financially and time consuming and that the aids to the activities could be used multiple times. Maps and cards for the activities were created on underlying images available at Freepik.com providing free vector graphics. In order to make the activity interesting for children, eyecatching images were preferred and subsequently edited in Adobe Illustrator software.

Four didactic games and one experiment were used in the event focusing on understanding the map content, knowledge of continents and selected states of the world, determination of the natural environment of animals and their subsequent localization on the map of the world and observation of the formation of clouds. Since 2016, the VEDET event is organized annually at the Faculty of Natural Sciences, Constantine the Philosopher University in Nitra with about 400 children coming from kindergartens and 1st grade of primary schools. The didactic games and experiments used at the event extend the geography teaching to new elements and enrich children in pre-school age with new experience.

Mgr. Michaela Žoncová, PhD.

Katedra geografie a geológie FPV UMB v Banskej Bystrici

Tajovského 40, 97401 Banská Bystrica

E-mail: michaela.zoncova@umb.sk

Mgr. Jana Vojteková, PhD.

Katedra geografie a regionálneho rozvoja FPV UKF v Nitre

Trieda A. Hlinku 1, 94974 Nitra

E-mail: jvojtekova@ukf.sk 